\title{
Development Status of the Fission Power System Technology Demonstration Unit
}

Maxwell H. Briggs, Marc A. Gibson, and Steven M. Geng

Glenn Research Center, Cleveland, Ohio

Jon Boise Pearson

Marshall Space Flight Center, Huntsville, Alabama

Thomas Godfroy

Maximum Technology Corporation, Huntsville, Alabama 


\section{NASA STI Program . . . in Profile}

Since its founding, NASA has been dedicated to the advancement of aeronautics and space science. The NASA Scientific and Technical Information (STI) program plays a key part in helping NASA maintain this important role.

The NASA STI Program operates under the auspices of the Agency Chief Information Officer. It collects, organizes, provides for archiving, and disseminates NASA's STI. The NASA STI program provides access to the NASA Aeronautics and Space Database and its public interface, the NASA Technical Reports Server, thus providing one of the largest collections of aeronautical and space science STI in the world. Results are published in both non-NASA channels and by NASA in the NASA STI Report Series, which includes the following report types:

- TECHNICAL PUBLICATION. Reports of completed research or a major significant phase of research that present the results of NASA programs and include extensive data or theoretical analysis. Includes compilations of significant scientific and technical data and information deemed to be of continuing reference value. NASA counterpart of peer-reviewed formal professional papers but has less stringent limitations on manuscript length and extent of graphic presentations.

- TECHNICAL MEMORANDUM. Scientific and technical findings that are preliminary or of specialized interest, e.g., quick release reports, working papers, and bibliographies that contain minimal annotation. Does not contain extensive analysis.

- CONTRACTOR REPORT. Scientific and technical findings by NASA-sponsored contractors and grantees.
- CONFERENCE PUBLICATION. Collected papers from scientific and technical conferences, symposia, seminars, or other meetings sponsored or cosponsored by NASA.

- SPECIAL PUBLICATION. Scientific, technical, or historical information from NASA programs, projects, and missions, often concerned with subjects having substantial public interest.

- TECHNICAL TRANSLATION. Englishlanguage translations of foreign scientific and technical material pertinent to NASA's mission.

Specialized services also include creating custom thesauri, building customized databases, organizing and publishing research results.

For more information about the NASA STI program, see the following:

- Access the NASA STI program home page at http://www.sti.nasa.gov

- E-mail your question to help@sti.nasa.gov

- Fax your question to the NASA STI Information Desk at 443-757-5803

- Phone the NASA STI Information Desk at 443-757-5802

- Write to: STI Information Desk NASA Center for AeroSpace Information 7115 Standard Drive Hanover, MD 21076-1320 
NASA/TM-2012-217717

AIAA-2012-3711

\section{Development Status of the Fission Power System Technology Demonstration Unit}

Maxwell H. Briggs, Marc A. Gibson, and Steven M. Geng

Glenn Research Center, Cleveland, Ohio

Jon Boise Pearson

Marshall Space Flight Center, Huntsville, Alabama

Thomas Godfroy

Maximum Technology Corporation, Huntsville, Alabama

Prepared for the

10th International Energy Conversion Engineering Conference (IECEC)

sponsored by the American Institute of Aeronautics and Astronautics

Atlanta, Georgia, July 30 to August 1, 2012

National Aeronautics and

Space Administration

Glenn Research Center

Cleveland, Ohio 44135 
Trade names and trademarks are used in this report for identification only. Their usage does not constitute an official endorsement, either expressed or implied, by the National Aeronautics and Space Administration.

Level of Review: This material has been technically reviewed by technical management.

Available from

NASA Center for Aerospace Information 7115 Standard Drive

Hanover, MD 21076-1320
National Technical Information Service 5301 Shawnee Road Alexandria, VA 22312

Available electronically at http://www.sti.nasa.gov 


\title{
Development Status of the Fission Power System Technology Demonstration Unit
}

\author{
Maxwell H. Briggs, Marc A. Gibson, and Steven M. Geng \\ National Aeronautics and Space Administration \\ Glenn Research Center \\ Cleveland, Ohio 44135 \\ Jon Boise Pearson \\ National Aeronautics and Space Administration \\ Marshall Space Flight Center \\ Huntsville, Alabama 35812 \\ Thomas Godfroy \\ Maximum Technology Corporation \\ Huntsville, Alabama 35814
}

\begin{abstract}
This paper summarizes the progress that has been made in the development of the Fission Power System Technology Demonstration Unit (TDU). The reactor simulator core and Annular Linear Induction Pump have been fabricated and assembled into a test loop at the NASA Marshall Space Flight Center. A $12 \mathrm{kWe}$ Power Conversion Unit (PCU) is being developed consisting of two 6 kWe free-piston Stirling engines. The two $6 \mathrm{kWe}$ engines have been fabricated by Sunpower Inc. and are currently being tested separately prior to integration into the PCU. The Facility Cooling System (FCS) used to reject convertor waste heat has been assembled and tested at the NASA Glenn Research Center (GRC). The structural elements, including a Buildup Assembly Platform (BAP) and Upper Truss Structure (UTS) have been fabricated, and will be used to test cold-end components in thermal vacuum prior to TDU testing. Once all components have been fully tested at the subsystem level, they will be assembled into an end-to-end system and tested in thermal vacuum at GRC.
\end{abstract}

\section{Nomenclature}

$\begin{array}{ll}\text { AFSP } & \text { Affordable Fission Surface Power } \\ \text { ALIP } & \text { Annular Linear Induction Pump } \\ \text { ATC } & \text { ALIP Test Circuit } \\ \text { BAP } & \text { Buildup Assembly Platform } \\ \text { BOP } & \text { Balance of Plant } \\ \text { FCS } & \text { Facility Cooling System } \\ \text { FPS } & \text { Fission Power System } \\ \text { GRC } & \text { NASA Glenn Research Center } \\ \text { INL } & \text { Idaho National Laboratory } \\ \text { LANL } & \text { Los Alamos National Laboratory } \\ \text { MSFC } & \text { Marshall Space Flight Center } \\ \text { NaK } & \text { Sodium-Potassium Eutectic } \\ \text { ORNL } & \text { Oak Ridge National Laboratory } \\ \text { PCU } & \text { Power Conversion Unit }\end{array}$


RxSim Reactor Simulator NaK Loop

SNL Sandia National Laboratories

TDU Technology Demonstration Unit

TRL Technology Readiness Level

UTS Upper Truss Structure

WHX Waste Heat Exchanger

\section{Introduction}

The Fission Power System (FPS) team is developing technologies for an affordable FPS to support future exploration missions. The FPS Initial Concept Definition (Ref. 1) is based on surface power applications, using a below-grade reactor and vertical truss to support Balance of Plant (BOP) components (Fig. 1).

This FPS uses a single fast-spectrum uranium dioxide reactor to heat a liquid sodium-potassium eutectic (NaK). A pair of fully-redundant Annular Linear Induction Pumps (ALIPs) are used to circulate the NaK to a pair of intermediate heat exchangers (IHX). The IHX is a NaK-to-NaK heat exchanger that provides a buffer between the reactor and the BOP. Each of the two intermediate NaK loops service two PCUs. There are four water heat rejection loops (one for each PCU) that transfers the waste heat to two radiator wings (two loops per wing). A more detailed description of the FPS reference concept is given in Reference 1.

The FPS Technology Demonstration Unit (TDU) is designed to raise the Technology Readiness Level (TRL) of FPS technology by demonstrating end-to-end system performance and robustness in a relevant environment. The TDU will be a full-scale demonstration of the primary FPS components (excluding the nuclear reactor). The TDU accomplishes this by combining a single NaK loop with a non-nuclear core simulator, an ALIP, a 12 kWe PCU, a water heat rejection loop, and a radiator, for an end-to-end system test in a thermal vacuum test chamber (Refs. 2 and 3). Figures 2 and 3 show a schematic and an artistic rendering of the TDU, respectively.

The hot-end subsystem, which includes the core simulator, ALIP, volume accumulator, and custom instrumentation, is referred to as the RxSim (Reactor Simulator NaK Loop), and will be tested at the NASA Marshall Space Flight Center (MSFC). PCU subsystem testing will occur at Sunpower, Inc. Cold-end subsystem testing, including the water pump, volume accumulator, facility cooling system, and subscale radiators, will be tested at NASA Glenn Research Center (GRC). When these tests have concluded, all subsystems will be delivered to GRC and assembled into the TDU where it will be tested as an end-to-end system.

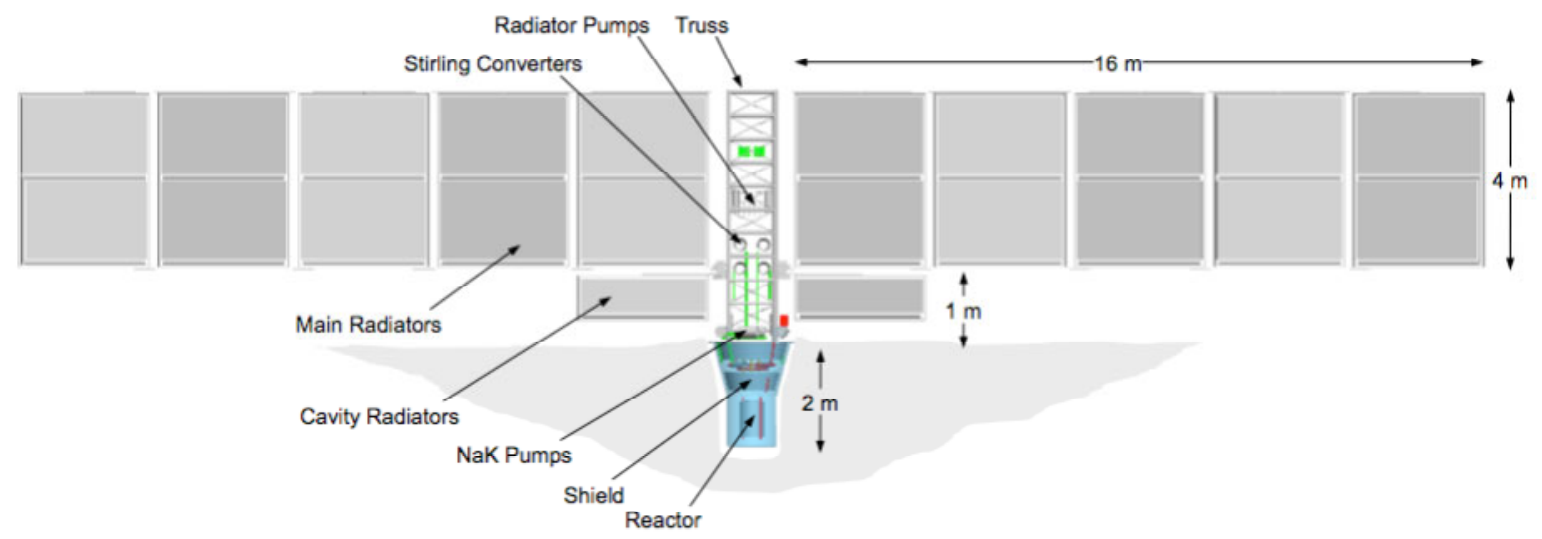

Figure 1._Affordable FPS configured for surface power applications. 


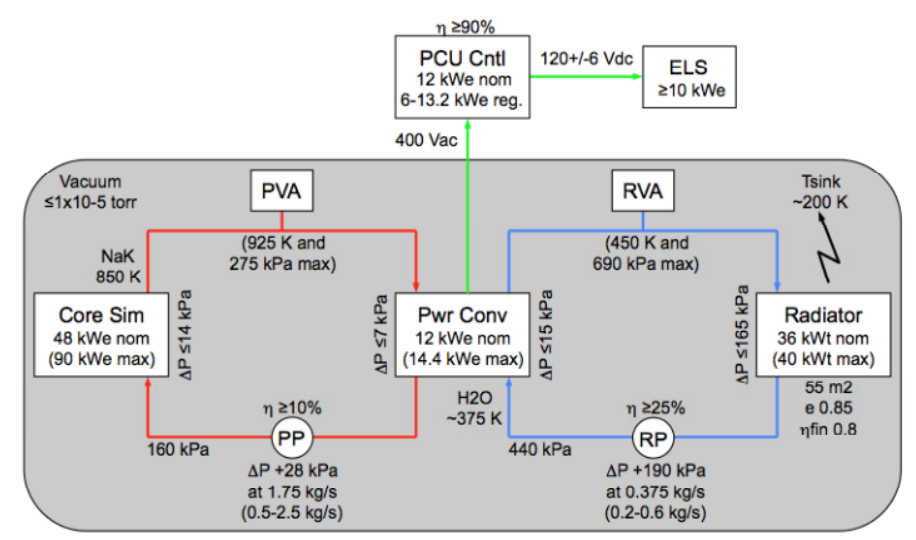

Figure 2.-TDU schematic.

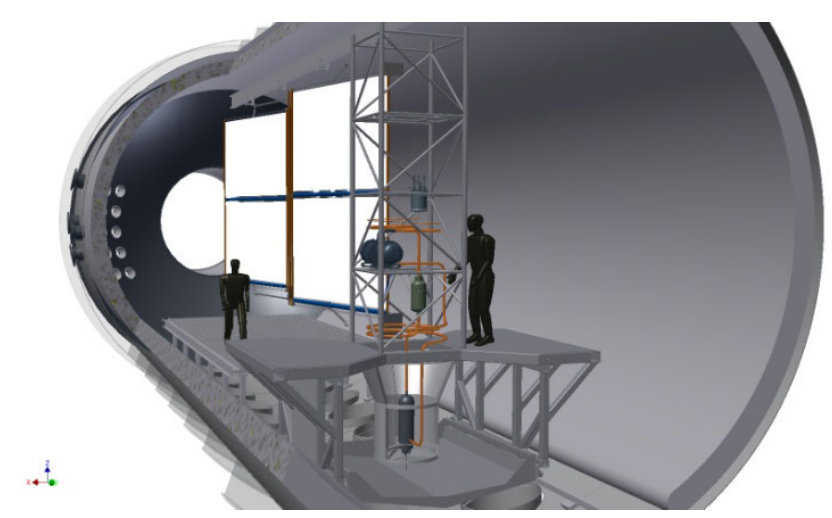

Figure 3.-TDU assembly in GRC thermal vacuum facility.

\section{TDU Component Development}

This section gives a brief description of the TDU component fabrication status, plans for testing, and references to more detailed information.

\section{Core Simulator}

Core simulators are designed to thermo-hydraulically mimic the behavior of a nuclear core. Nuclear fuel rods are replaced with electrically heated thermal simulators with the same dimensions and thermal power (Ref. 4). A variety of core simulators have been built and tested by MSFC, including heat-pipecooled, gas-cooled, and liquid-metal- cooled designs. These reactor simulators have been coupled with a control system that enables them to respond to thermal transients in a similar fashion to a real reactor, by incorporating a software-based reactivity feedback control algorithm (Ref. 5).

The nuclear reactor core design for FPS was done by the Los Alamos National Laboratory (LANL) during the Affordable Fission Surface Power (AFSP) Study (Ref. 6). The 37-pin NaK-cooled design FPS design has a nominal power of $200 \mathrm{~kW}$. The core simulator built for the TDU has a nominal thermal power of $45 \mathrm{~kW}$, with a peak power capability of $100 \mathrm{~kW}$. The TDU core simulator is FPS sized, but only provides the power needed for a single PCU. Thermal simulator rods were custom built by MSFC for use in the TDU core (Ref. 7). The control system is being designed to mimic the behavior of the AFSP reactor (Ref. 8). The core simulator control system hardware was assembled by Oak Ridge National Laboratory (ORNL), data acquisition and control software was written by MSFC, and reactivity feedback control software was developed by Sandia National Laboratories (SNL) based on reactor kinetics calculations performed by LANL (Ref. 9). Figures 4 and 5 show a three-dimensional rendering of the core simulator and the fabricated core simulator installed in the RxSim loop, respectively. 


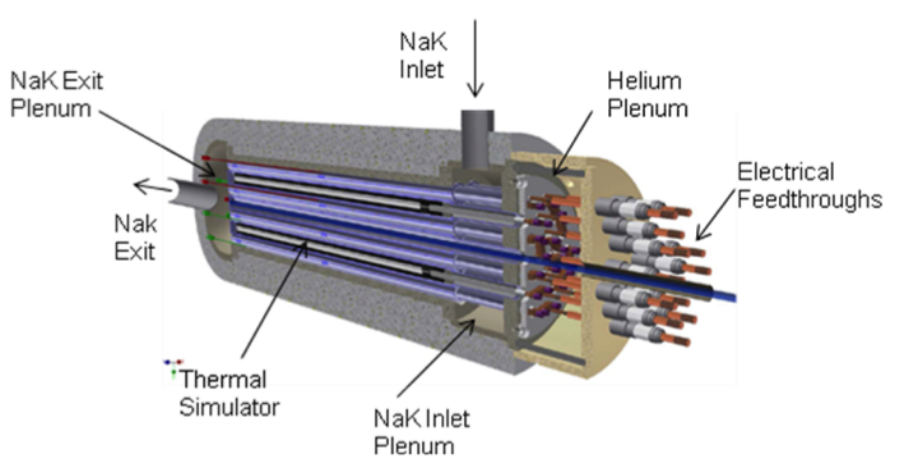

Figure 4.-Cutaway view of TDU core simulator.

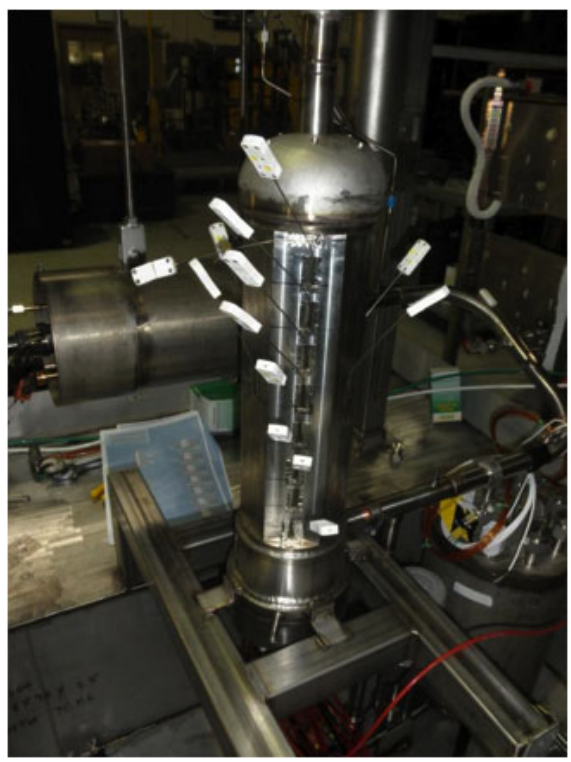

Figure 5.-Core simulator installed in RxSim at MSFC.

\section{Annular Linear Induction Pump (ALIP)}

An Annular Linear Induction Pump (ALIP) is an electromagnetic liquid metal pump with no moving parts. ALIPs were chosen for the FPS because of their high reliability and long-life operation. Two ALIPs were designed and fabricated by the Idaho National Laboratory (INL). One of the ALIPs was designed specifically for use in the TDU to deliver full NaK flow to a single PCU. The other pump was a prototypic FPS pump, capable of delivering full NaK flow to four PCUs.

Both pumps have been fabricated and tested in the ALIP Test Circuit (ATC) at MSFC (Refs. 11 and 12). These tests defined the operating envelope and measured steady-state performance and transient response of the pumps. The TDU ALIP is currently being tested with the core simulator and other hot-end components in the RxSim loop at MSFC. Figure 6 shows the TDU ALIP installed in the ATC.

\section{Stirling Power Conversion Unit}

The 12-kWe Stirling PCU and electronic controller are being developed by Sunpower, Inc., of Athens, Ohio, under contract to NASA GRC. The 12-kWe PCU is composed of two 6-kWe free-piston Stirling engines that are joined (thermodynamically coupled) at their hot ends as shown in Figure 7 . This dual-opposed configuration results in a dynamically balanced mechanical system. In this configuration, the two engines share a common expansion space and are rigidly connected in the hot region. The rigid 


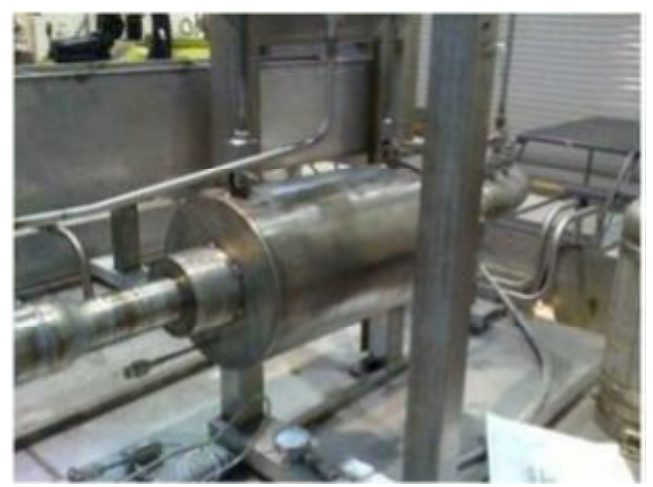

Figure 6.-TDU ALIP installed in ATC at MSFC.

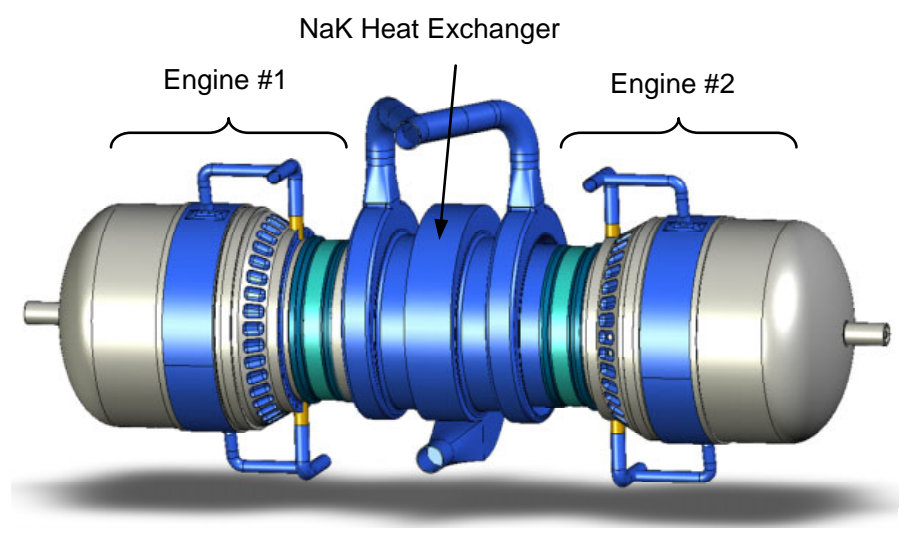

Figure 7.-12-kWe Stirling PCU.

connection minimizes forces that are transmitted to external attachments such as the plumbing. This configuration also results in a smaller footprint and a simplified heater head design. The unit is designed to produce $12 \mathrm{kWe}$ at the operating conditions of a $570{ }^{\circ} \mathrm{C}$ hot-end temperature, a $111^{\circ} \mathrm{C}$ cold-end temperature, and a mean working space pressure of $6.2 \mathrm{MPa}$. The design frequency is $60 \mathrm{~Hz}$ and the working fluid is helium. The unit is about $1.1 \mathrm{~m}$ in length and $0.3 \mathrm{~m}$ in diameter and weighs about $190 \mathrm{~kg}$.

The PCU features a unique NaK heat exchanger heater head. This heater head allows the PCU to be integrated with a pumped NaK loop, which is the method chosen in the FPS reference concept for transporting thermal energy from the heat source to the Stirling PCU. The heat exchanger is designed assuming NaK-78 (78 percent $\mathrm{K}$ and 22 percent $\mathrm{Na}$ ) at a supply temperature of $577^{\circ} \mathrm{C}$, pressure of $150 \mathrm{kPa}$, and flow rate of $1.75 \mathrm{~kg} / \mathrm{s}$. The use of $\mathrm{NaK}$ for heat input and the use of the thermodynamically coupled configuration have both been tested and proven with subscale component tests (Refs. 13 to 15).

A PCU electronic controller has been designed and built that features the key characteristics required for the FPS application. The controller is capable of (1) synchronizing the piston amplitudes of the two engines, (2) constant command frequency operation, (3) controlling the engine piston amplitudes thereby modulating power output from zero to full power, (4) dissipating any unused power (i.e., power not consumed by the user load), and (5) converting the output voltage to $120 \mathrm{~V}$ dc. The controller (excluding the DC-DC convertor) has been successfully tested on a pair of 1-kWe convertors that are similar in design to the 6-kWe PCU convertors. The controller will be tested further after the PCU has been assembled. A more complete description of the PCU and controller can be found in Reference 16. 


\section{Structural Components}

The TDU structural components can be broken into two main pieces, the Buildup Assembly Platform (BAP) and the Upper Truss Structure (UTS) (Fig. 8). The BAP is a facility integration structure that provides support for all systems and personnel. The BAP will use the existing facility rail system to move in and out of the chamber to facilitate modifications and additions to test components throughout the test program. The BAP was designed as a mating adapter between the power conversion systems on the upper half and the reactor simulator system on the lower half. During TDU preparations, this will allow parallel fabrication and buildup as systems from several team centers are combined.

Attached to the top of the BAP is the UTS, which will support all the power conversion and heat rejection components. The UTS was designed to emulate a full-scale 40-kWe fission surface power truss structure (Fig. 1) that would allow all the components to be mounted in a representative arrangement. This design will allow a higher fidelity TDU test as well as accommodate future additions of multiple PCUs, deployable radiator arrays, PMAD systems, and other additions that support future development without the cost of rebuilding.

\section{Water Pump for Thermal Vacuum}

The TDU water pump must pump high-pressure, high-temperature water and operate in vacuum, without convective cooling of the motor. This requires the use of high-temperature motors, the ability to cool the motor with the process fluid, and hermetic sealing of the process fluid. A commercial pump from the Nikisso Company met these requirements and is shown schematically in Figure 9. This pump has been delivered to GRC and will be tested with other cold-end components in thermal vacuum at GRC prior to TDU assembly.

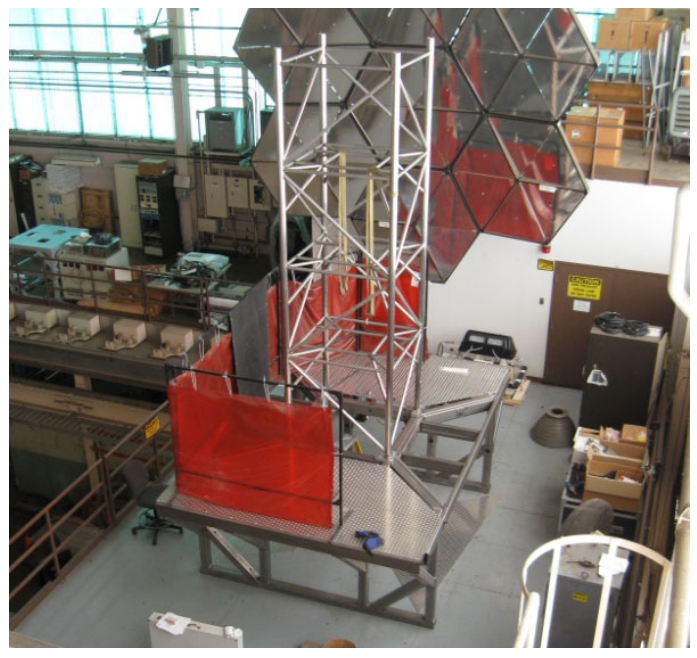

Figure 8.-UTS mounted to BAP at GRC.

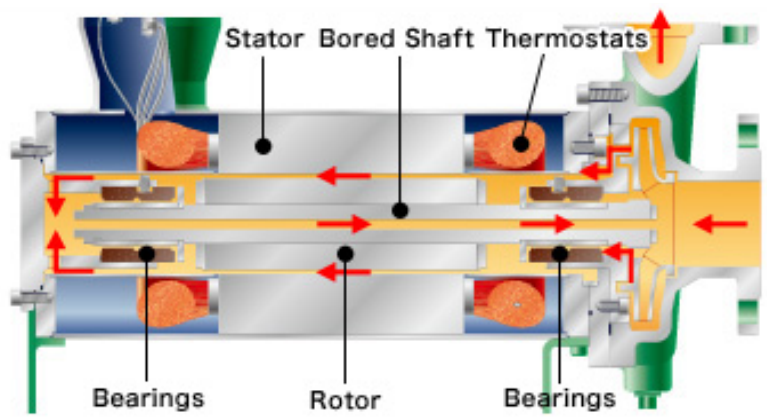

Figure 9.-Hermetically sealed self-cooling water pump. 


\section{Waste Heat Exchanger (WHX)}

The WHX is a water-to-forced-air heat exchanger that is used to reject waste heat from the PCU during TDU testing. The WHX is a commercially available unit designed to reject $52 \mathrm{~kW}_{\mathrm{t}}$ at the TDU nominal conditions of $0.375 \mathrm{~kg} / \mathrm{s}$ water flow at $400 \mathrm{~K}$. The heat rejection can be tuned to a specific value by controlling the forced convection on the fin-side of the heat exchanger. The WHX was assembled into a test loop and both performance and control were verified at GRC. Figure 10 shows the WHX outside of the vacuum chamber at GRC.

\section{Affordable Radiator Proof of Concept}

The original TDU test plan called for two phases of testing. In the first phase, PCU cooling would be provided by a pumped water loop coupled to the WHX, which rejects heat to ambient air outside of the vacuum chamber. This phase of testing is not a true end-to-end system because the radiators, a major FPS component, are not present. During the second phase of testing, the WHX was to be replaced with prototypic radiators (Ref. 17) allowing for a true end-to-end system test. However, budget reductions have eliminated the second phase of TDU testing. Without an end-to-end system test it is impossible to advance FPS technology beyond TRL 5, which reduces the scope of TDU testing.

In response, the FPS team has developed an affordable radiator design, focused on cost reduction and maintaining radiator performance (Ref. 18). This radiator could provide an affordable option for restoring the original scope of the TDU. The affordable radiator design reduces cost by eliminating high-cost materials, reducing the overall number of components, and simplifying processing and assembly. The original design called for two carbon-carbon facesheets to be bonded to heat pipes through a POCO foam saddle. The new design uses a single aluminum facesheet bonded directly to each heat pipe, resulting in a dramatic reduction in both cost and weight. The difference in these panel layouts is shown in Figure 11.

The FPS team has not tested single facesheet designs as thoroughly as dual facesheet designs, so single facesheet designs are considered a higher technical risk. In order to reduce this technical risk, a proof-of-concept radiator, based on the new design, has been fabricated and will be tested in thermal vacuum to verify functionality and performance.

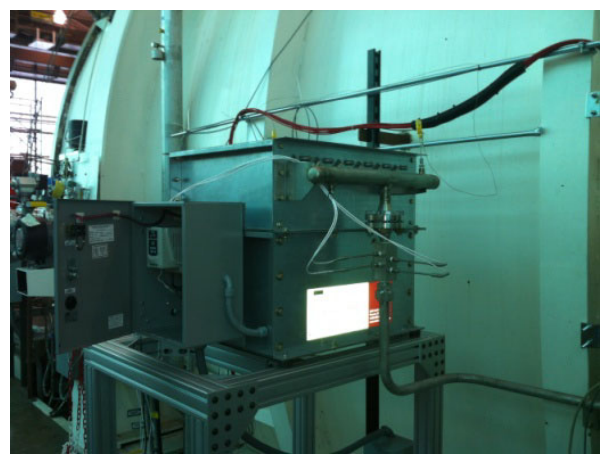

Figure 10.-WHX outside of vacuum chamber at GRC.

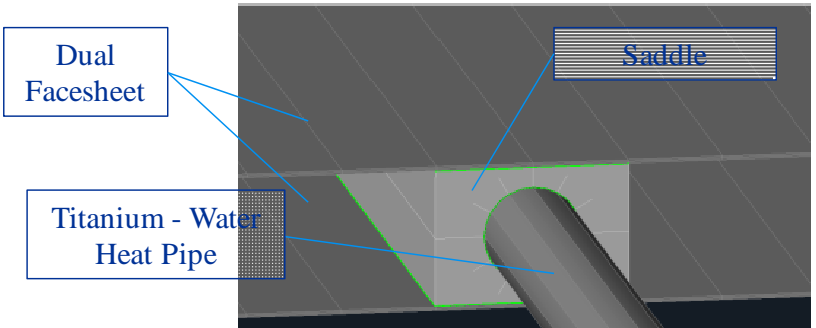

(a)

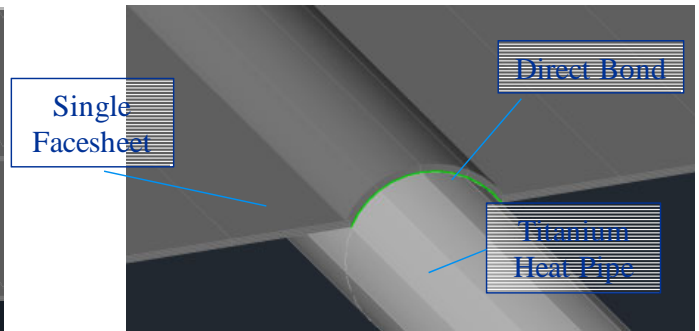

(b)

Figure 11.-Comparison of (a) dual facesheet and (b) single facesheet panel layouts. 


\section{Subsystem Testing Status}

\section{Reactor Simulator Loop}

The RxSim consists of the pumped NaK loop and all of its components except for the PCU, and its purpose is to deliver hot NaK to the PCU (Ref. 19). The RxSim consists of the core simulator, ALIP, elctromagnetic flow meter, cold trap, and volume accumulator. It also includes the control system, lower reservoir, gas-to-NaK heat exchanger (in place of the PCU), and all associated instrumentation. The RxSim has been assembled and is currently being tested at MSFC, prior to shipment to GRC, where the PCU and heat rejection will be integrated, and the full TDU tested in a thermal-vacuum environment. The RxSim test will allow all its components to be checked out as an integrated system. Figure 12 shows the RxSim loop outside of the vacuum facility at MSFC.

\section{Power Conversion Testing}

Since the PCU consists of two Stirling engines, Sunpower decided to build, test, and verify the engines individually prior to integration into the PCU. Electrically heated test heads were fabricated to allow for single-engine operation. In this configuration, the engines are bolted to a large mass (4000 lb) to minimize housing motion.

Fabrication of engine \#1 was completed in the Fall of 2011. Checkout testing began in October and full-power operation (6.1 kWe) was demonstrated in December 2011. Figure 13 shows engine \#1 on test at Sunpower with the heater head insulation removed. A series of thirty 1-kWe cartridge heaters (allows for insulation losses) were used to supply thermal energy to the heater head. Fabrication of engine \#2 was completed in the Spring of 2012, and check-out testing began in May of 2012.

After satisfactory performance is achieved for each engine, the two engines will be tested in a dualopposed, thermodynamically coupled configuration using an electrically heated dual engine test head. After successful operation using the electrically heated head, the PCU will be reassembled with the NaK heat exchanger heater head in preparation for delivery to NASA GRC. Delivery is expected by August 2013. The PCU will then be integrated into the TDU at NASA GRC for full-scale system demonstration testing.

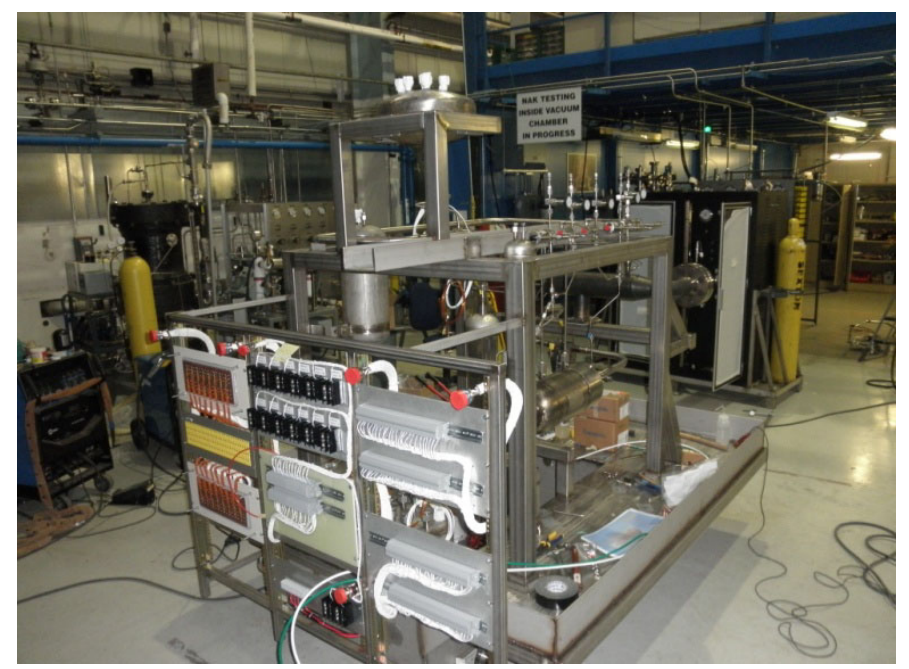

Figure 12.--RxSim loop at MSFC. 


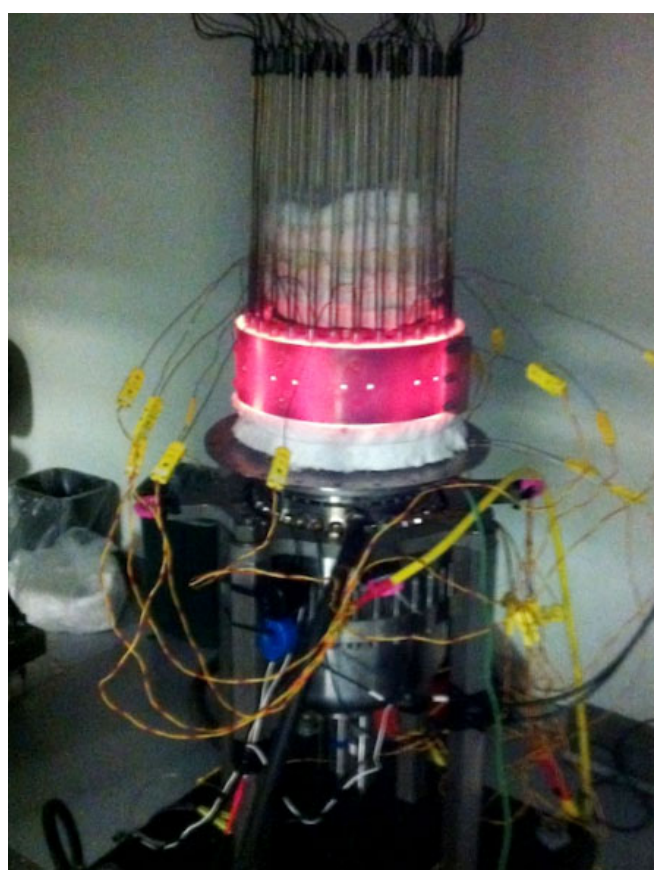

Figure 13.-Engine \#1 on test at Sunpower.

\section{Cold-End Testing}

Cold-end testing consists of subsystem testing and radiator proof-of-concept testing. During subsystem testing, the water pump and volume accumulator will be mounted on the UTS and tested in vacuum at GRC. This test will be used to validate fill, drain, and emergency cooling procedures to verify system functionality and to document pump performance.

Radiator proof-of-concept testing will be used to verify functionality, measure radiator performance, and validate detailed radiator models. The results of this test will be used to finalize the TDU radiator design. Once the design is finalized, the team will have more accurate cost estimates, which could be used to assess the feasibility of building radiators for TDU, returning it to an end-to-end system demonstration.

\section{Conclusion}

The Fission Power System (FPS) project is a hardware-focused project that strives to demonstrate component and system technologies through rigorous testing. The focus of this project is the Technology Demonstration Unit (TDU), an end-to-end system demonstration of an FPS, which is currently scheduled to begin testing in early 2014. Subscale and full-scale component testing and demonstration have been completed. Full-scale TDU components have been fabricated and are being assembled into subsystems to be tested at Glenn Research Center, Sunpower, Inc., and Marshall Space Flight Center. These subsystem tests are either being conducted or are in the buildup phase and are on schedule for the start of TDU testing in early 2014. The FPS team, consisting of many NASA, Department of Energy, and industry partners, has showed clear progress toward achieving the goal of a non-nuclear system-level demonstration of an FPS. 


\section{References}

1. Fission Surface Power Team, "Fission Surface Power System Initial Concept Definition,” NASA/TM-2010-216772, 2010.

2. Mason, L., et al., "Design and Test Plans for a Non-Nuclear Fission Power System Technology Demonstration Unit,” NASA/TM-2011-217100, 2011.

3. Palac, D., Mason, L., Houts, M., Harlow, S., "Fission Surface Power Technology Development Update,” NASA/TM-2011-216976, 2011.

4. Bragg-Sitton, S.M., et al., "Heater Development, Fabrication, and Testing: Analysis of Fabricated Heaters,” NASA/TM-2008-215466, 2008.

5. Bragg-Sitton, S., Webster, K., “Application of Simulated Reactivity Feedback in Non-Nuclear Testing of a Direct Drive Gas Cooled Reactor,” Internal MSFC report ER11-05-WI4c4-001, 2005.

6. Mason, L., Poston, D., Qualls, L., "System Concepts for Affordable Fission Surface Power," NASA/TM-2008-215166, 2008.

7. Garber, A., Pearson, J.B., "Design and Test of Advanced Thermal Simulators for an Alkali MetalCooled Reactor Simulator,” Nuclear and Emerging Technologies for Space, 2011.

8. Poston, D., "System Modeling Comparisons of the Fission Surface Power (FSP) System and the FSP Technology Demonstration Unit,” Nuclear and Emerging Technologies for Space, 2011.

9. Dughie, D., Dixon, D., Poston, D., "Calculation of Kinetics Parameters for the Affordable Fission Surface Power Reference Design,” Nuclear and Emerging Technologies for Space, 2011.

10. Polzon, K., et al., "Performance Testing of a Prototypic Annular Linear Induction Pump for Fission Surface Power,” NASA/TP—2010-216430, 2010.

11. Adkins, H., Werner, J.E., "Analysis of the Fission Surface Power Annular Linear Induction Pump Design Tools Based on Performance Test Results,” Idaho National Laboratory Technical Report INL/EXT-10-18211, Idaho Falls, ID, 2010.

12. Polzin, K., "Performance Testing of an Annular Linear Induction Pump for Incorporation into a Fission Power System Technology Demonstration Unit” (To be published)

13. Geng, S., Briggs, M., Hervol, D., "Performance of a Kilowatt-Class Stirling Power Conversion System in a Thermodynamically Coupled Configuration," Nuclear and Emerging Technologies for Space, Paper 3269, 2011.

14. Briggs, M., Geng, S., Pearson, J., Godfroy, T., "Summary of Test Results from a 1 kWe-Class FreePiston Stirling Power Convertor Integrated with a Pumped NaK Loop,” International Energy Conversion Engineering Conference, Paper 7173, 2010.

15. Briggs, M., "Dynamic Behavior of Kilowatt Class Stirling Convertors with Coupled Expansion Spaces,” Nuclear and Emerging Technologies for Space, Paper 3032, 2012.

16. Wood, G., Buffalino, A., Holliday, E., Penswick, B., Gedeon, G., "Free-Piston Stirling Power Conversion Unit for Fission Surface Power, Phase I Final Report,” NASA/CR-2010-216750, 2010.

17. Ellis, D., Calder, J., Siamidis, J., "Summary of the Manufacture, Testing and Model Validation of a Full-Scale Radiator for Fission Surface Power Applications,” Nuclear and Emerging Technologies for Space, Paper 3181, 2011.

18. Briggs, M., "Conceptual Design of an Affordable Radiator for the Fission Power System Technology Demonstration Unit,” Nuclear and Emerging Technologies for Space, Paper 3031, 2012.

19. Godfroy, T., Pearson, B., Webster, K., "Build Status of Reactor Simulator for Fission Surface Power Technology Demonstration Unit,” Nuclear and Emerging Technologies for Space, Paper 3092, 2012. 



\begin{tabular}{|c|c|c|}
\hline \multicolumn{2}{|c|}{ REPORT DOCUMENTATION PAGE } & $\begin{array}{l}\text { Form Approved } \\
\text { OMB No. 0704-0188 }\end{array}$ \\
\hline \multicolumn{3}{|c|}{ 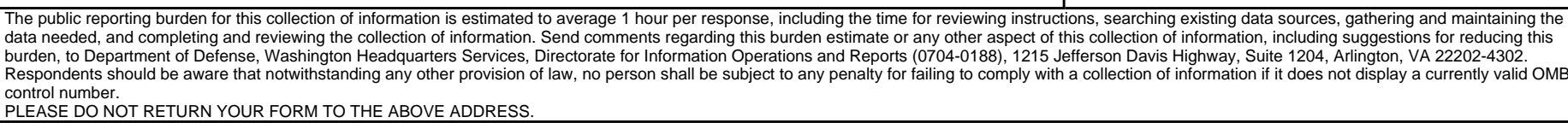 } \\
\hline $\begin{array}{l}\text { 1. REPORT DATE (DD-MM-YYYY) } \\
01-09-2012\end{array}$ & $\begin{array}{l}\text { 2. REPORT TYPE } \\
\text { Technical Memorandum }\end{array}$ & 3. DATES COVERED (From - To) \\
\hline \multirow{3}{*}{\multicolumn{2}{|c|}{$\begin{array}{l}\text { 4. TITLE AND SUBTITLE } \\
\text { Development Status of the Fission Power System Technology Demonstration Unit }\end{array}$}} & 5a. CONTRACT NUMBER \\
\hline & & 5b. GRANT NUMBER \\
\hline & & 5c. PROGRAM ELEMENT NUMBER \\
\hline \multirow{3}{*}{\multicolumn{2}{|c|}{$\begin{array}{l}\text { 6. AUTHOR(S) } \\
\text { Briggs, Maxwell, H.; Gibson, Marc, A.; Geng, Steven, M.; Pearson, Jon, Boise ; Godfroy, } \\
\text { Thomas }\end{array}$}} & 5d. PROJECT NUMBER \\
\hline & & 5e. TASK NUMBER \\
\hline & & $\begin{array}{l}\text { 5f. WORK UNIT NUMBER } \\
\text { WBS } 887359.01 .04\end{array}$ \\
\hline \multicolumn{2}{|c|}{$\begin{array}{l}\text { 7. PERFORMING ORGANIZATION NAME(S) AND ADDRESS(ES) } \\
\text { National Aeronautics and Space Administration } \\
\text { John H. Glenn Research Center at Lewis Field } \\
\text { Cleveland, Ohio 44135-3191 }\end{array}$} & $\begin{array}{l}\text { 8. PERFORMING ORGANIZATION } \\
\text { REPORT NUMBER } \\
\text { E-18230 }\end{array}$ \\
\hline \multirow{2}{*}{\multicolumn{2}{|c|}{$\begin{array}{l}\text { 9. SPONSORING/MONITORING AGENCY NAME(S) AND ADDRESS(ES) } \\
\text { National Aeronautics and Space Administration } \\
\text { Washington, DC 20546-0001 }\end{array}$}} & $\begin{array}{l}\text { 10. SPONSORING/MONITOR'S } \\
\text { ACRONYM(S) } \\
\text { NASA }\end{array}$ \\
\hline & & $\begin{array}{l}\text { 11. SPONSORING/MONITORING } \\
\text { REPORT NUMBER } \\
\text { NASA/TM-2012-217717 }\end{array}$ \\
\hline \multicolumn{3}{|c|}{$\begin{array}{l}\text { 12. DISTRIBUTIONIAVAILABILITY STATEMENT } \\
\text { Unclassified-Unlimited } \\
\text { Subject Category: } 20 \\
\text { Available electronically at http://wWw.sti.nasa.gov } \\
\text { This publication is available from the NASA Center for AeroSpace Information, 443-757-5802 }\end{array}$} \\
\hline
\end{tabular}

\section{SUPPLEMENTARY NOTES}

\section{ABSTRACT}

This paper summarizes the progress that has been made in the development of the Fission Power System Technology Demonstration Unit (TDU). The reactor simulator core and Annular Linear Induction Pump have been fabricated and assembled into a test loop at the NASA Marshall Space Flight Center. A 12 kWe Power Conversion Unit (PCU) is being developed consisting of two 6 kWe free-piston Stirling engines. The two $6 \mathrm{kWe}$ engines have been fabricated by Sunpower Inc. and are currently being tested separately prior to integration into the PCU. The Facility Cooling System (FCS) used to reject convertor waste heat has been assembled and tested at the NASA Glenn Research Center (GRC). The structural elements, including a Buildup Assembly Platform (BAP) and Upper Truss Structure (UTS) have been fabricated, and will be used to test cold-end components in thermal vacuum prior to TDU testing. Once all components have been fully tested at the subsystem level, they will be assembled into an end-to-end system and tested in thermal vacuum at GRC.

\section{SUBJECT TERMS}

Stirling power conversion; Linear alternator; Power conversion; Heat rejection; Nuclear power systems; Dynamic power conversion; Power; Electromagnetic pump

\begin{tabular}{|c|c|c|c|c|c|}
\hline \multicolumn{3}{|c|}{ 16. SECURITY CLASSIFICATION OF: } & \multirow{2}{*}{$\begin{array}{l}\text { 17. LIMITATION OF } \\
\text { ABSTRACT } \\
\text { UU }\end{array}$} & \multirow{2}{*}{$\begin{array}{l}\text { 18. NUMBER } \\
\text { OF } \\
\text { PAGES } \\
18\end{array}$} & \multirow{2}{*}{$\begin{array}{l}\text { 19a. NAME OF RESPONSIBLE PERSON } \\
\text { STI Help Desk (email:help@sti.nasa.gov) } \\
\text { 19b. TELEPHONE NUMBER (include area code) } \\
\text { 443-757-5802 }\end{array}$} \\
\hline $\begin{array}{l}\text { a. REPORT } \\
U\end{array}$ & $\begin{array}{l}\text { b. ABSTRACT } \\
U\end{array}$ & $\begin{array}{l}\text { c. THIS } \\
\text { PAGE } \\
\text { U }\end{array}$ & & & \\
\hline
\end{tabular}



